$\triangle C T A \mathbb{N E O P H I L O L O G I C A}$

DOI: 10.4312/an.50.1-2.25-36
UDK: [821.111(73).09:821.111.09]:178.1

\title{
Fortified Fiction: Writers and Drink
}

\section{Wojciech Klepuszewski}

\begin{abstract}
Part of what is usually labelled as drink/ing studies comprises literature and the way drink is rendered in literary works. In many cases such works are written by writers who themselves are drink-dependent. This article focuses on such fiction an such writers, acknowledging American literature, extensively discussed in various studies, and bringing to the fore some British novelists who largely remain at the margin of critical interest in this respect.
\end{abstract}

Key words: Alcohol, literature, fiction, writers, addiction. 
The fact that alcohol in many literary works flows in abundance inevitably leads to the question of the writer-drink-literature nexus. This particular junction may produce a variety of outcomes, though one has to bear in mind that while some writers' drinking propensity may trigger a literary representation, not every drink-dependent writer will necessarily write about addiction; conversely, a non-addicted writer may find interest in incorporating drink as a theme. Thus, the literary rendition may be utterly irrespective of the writer's habits, though of course, as the history of literature shows, the reverse is mostly true and when this is the case, literature becomes "an indirect outlet for the author to express ideas rooted in his own life experience." (Rostkoff 2002: 224). The most extreme variant of this peculiar life-writing brew are those writers who exemplify an organic fusion in this respect, meaning that what is a real-life feature is transposed to the fictional realm they create. In other words, each of these writers "transforms alcohol into ink" (Voelker 1997: 23), leaving a literary imprint of their own drinking habits. Obviously, this does not apply to writers for whom drink becomes an impediment, incapacitating their creativity or even leading to a complete writer's block, but to those who find some inspirational value in drink. This point is frequently discussed by scholars and critics, such as John Booth, the editor of Creative Spirits: A Toast to Literary Drinkers (1997):

The relationship between drink and writing is well established. It is all things to all writers: an encouragement, a support, a solace, a spur, an excuse. For some lucky individuals drink is liberating, galvanizing the imagination to life so the words pour, filling the white emptiness of the page. (1997: 1)

Much similar, but more empirically reinforced stance is expressed by the editor of Drink to Me Only (1982), Aland Bold, if only because of his great affection for both drinking and literary matters (cf. Smith 1983: 1697), the two collections of his poems, Society Inebrious (1965) and A Pint of Bitter (1971) being the literary outcomes of such fusion, and confirming Bold's expertise in the field:

There are few subjects authors are so eloquent about as drink: it not only loosens the tongue, its spirit constantly materializes on paper. Drink has inspired authors to spectacular feats of artistic invention; it has also encouraged a limitless loquacity or induced a wordless depression and despair. (1982: 1)

Bold's and Booth's anthologies are two examples of drink-themed compilations which allow the reader to become familiar with a large number of texts reflecting this particular literary and biographical aspect in poetry, drama, fiction and miscellaneous non-fictional pieces. There are also numerous critical studies, but they usually focus on American writers, with such legendary drinkers as Hemingway, Bukowski, McCullers, and Kerouac. Their novels reflect the authors' drinking 
habits, most often in the form of protagonists who consume prodigious amounts of alcohol, as happens in Raymond Chandler's detective novels featuring Philip Marlowe, a typical barfly. Marlowe's preferred drink is bourbon, but as we learn from, for instance, The Long Good-Bye (1953), he is 'never fussy about drinks' (1978: 18), easily accepting brandy, or mixes such as a whiskey sour. Marlow represents a philosophical type of drinker, often making comments concerning the act of drinking with all its implications, a good example being The Big Sleep (1939), in which he explains that "you can have a hangover from other things than alcohol" (159). Raymond Chandler himself had a long history of drink dependence, with "blackouts, or alcohol-induced amnesia, when he drank heavily." (Hiney 1997: 62).

Whereas Chandler's protagonist is simply a detective who drinks heavily, in more extreme variants the main characters fall at the very bottom of the social ladder, as is the case in Stephen King's The Shining (1977) and its sequel Doctor Sleep (2013), the former featuring Jack Torrance, with an alcoholic history behind, while the latter his son Danny, who inherited this particular feature from his father and, unsurprisingly, is referred to as, "a drunkass alcoholic" (2014: 89). Sam Leith writes about both books being a reflection of King's struggle with addiction, and defines The Shining as "a book by a drinking alcoholic about an alcoholic in the grip of white-knuckle abstinence" and Doctor Sleep as "a book about a recovering alcoholic written by a recovering alcoholic." (2013). Stephen King's own achievement in the field of alcohol consumption is impressive, particularly if one considers his alcoholic "stunts" such as drinking "a case of 16-ounce beer cans a night" (Rolls 2009: 81). In his On Writing: A Memoir of the Craft (2000), Stephen King openly admits to being drink-dependent:

Holy shit, I'm an alcoholic, I thought, and there was no dissenting opinion from inside my head - I was, after all, the guy who had written The Shining without even realizing (at least until that night) that I was writing about myself.( 2002: 88)

While some alcoholic writers left a noteworthy literary reflection of their drinking habits in fiction, others also contributed works of an autobiographical nature. The point in case is certainly Jack London's alcoholic memoir, John Barleycorn (1913), in which he writes of his addiction taking roots in the very childhood: "I was five years old the first time I got drunk" (1913: 16). A related type of fiction are 'recovery memoirs', such as Asylum (1935) by William Seabrook, a journalist and traveller who decided to spend some time at an asylum in 1933, to treat his acute alcoholism ${ }^{1}$, the record of which is left in Asylum. Considering that

1 Although Seabrook managed to stay sober for a while, there was a relapse into drinking which he described in his last book, No Hiding Place; An Autobiography (1942), one of the reflections there being an ominous projection of the finale to his own life: "What do drunkards do? They... drink... themselves... to... death." (1942: 385). 
Seabrook was a travel writer, contributing short texts to Cosmopolitan and Reader's Digest, as well as writing numerous books, such as Adventures in Arabia (1927) or The Magic Island (1929), Ryan Holiday's definition of the memoir as a "travel book where the journey is inward instead of outward" (2015) seems most appropriate. In fact, Asylum is full of Seabrook's reflections on this particular self-exploration:

So long as any man drinks when he wants to and stops when he wants to, he isn't a drunkard, no matter how much he drinks or how often he falls under the table. The British upper classes were constantly and consistently mildly stewed, from father to son, in Parliament and Pall Mall for nearly the whole of the eighteenth century. It isn't drinking that makes a drunkard. I had drunk for years, enthusiastically, and with pleasure, when I wanted to. Then something snapped in me and I lost control. I began to have it when I didn't want it. I couldn't stop when I wanted to. (1935: 53)

At the time, Seabrook's book was famous enough to be noticed by another alcoholic writer, Francis Scott Fitzgerald, who mentions it in his 1936 essay "The Crack-Up" (cf. Wilson 2009:71). However, the real profusion of recovery memoirs appeared in the second part of the twentieth-century and continues to do so. There are numerous examples of such in America, to mention Caroline Knapp's Drinking: A Love Story (1996), Note Found in a Bottle: My Life as a Drinker (1999), written by Susan Cheever, whose father was John Cheever, an alcoholic writer too. In Britain, among the examples worth mentioning is the novelist known for his continuation of the Bond series, John Gardner, and his autobiographical Spin the Bottle (1964), and more recently, John Sutherland's Last Drink to LA (2001).

However, all of these, written by struggling alcoholics, belong to the realm of non-fiction. As far as fiction is concerned, at least fame-wise, nothing compares to Charles Jackson's The Lost Weekend (1944) and Malcolm Lowry's Under the Volcano (1947), seminal books by writers who both took refuge in the bottle. Charles Jackson's The Lost Weekend (1944) features Don Birnam, a failed writer and alcoholic who is both comforted and confronted by alcohol. John Crowley asserts that the novel is a unique masterpiece of writing about alcoholic addiction, and that its "canny portrait of the alcoholic remains unsurpassed." (1993: 3). However, what made the book one of the most iconic renderings of the theme was the subsequent screening of the film version (1945), directed by Billy Wilder and awarded four Oscars. Paradoxically, it all started by accident:

Billy Wilder was on his way by train to New York for a holiday in the spring of 1944. He picked up a copy of Charles Jackson's novel The Lost Weekend at a kiosk during a stopover at Union Station in Chicago. Wilder sat up all night reading it. By the time he reached Pennsylvania Station in new York City the 
following morning, Wilder had finished the book. He was convinced that it would make an engrossing movie. (Phillips 2010: 71)

The immense success of the film exceeded the interest in the novel as such. Blake quotes Jackson, who complained that people would tell him how much they adored 'his' film, with no mention of reading the book. (cf. 2013: xviii). Judy Cornes, in her study Alcohol in the Movies, 1898-1962: A Critical History, writes that the film version of the novel "allows us to experience viscerally the slow disintegration of a sensitive, intelligent writer" (2006: 126), which sound as if the film were a brilliant version of an average novel, rather than equally brilliant novel. From the present perspective, both the novel and its film adaptation seem equally harrowing with their picture of the main protagonist's gradual fall into the drinking abyss. This process begins with Birnam having to fight the ever-growing shortage of drink supply ("one warm drop crawled like slow syrup through the neck of the bottle"; 1998: 40), only to reach the alcoholic nadir in the bout of delirium tremens, referred to as "a disease of the night" (154). However, these are the most glaring, almost clinical examples of alcoholism, but Jackson's novel offers a whole range of alcoholic intricacies:

When the drink was set before him, he felt better. He did not drink it immediately. Now that he had it, he did not need to. Instead, he permitted himself the luxury of ignoring it for a while; he lit a cigarette, took some envelopes out of his pocket and unfolded and glanced through an old letter, put them away again and began to hum, quietly. Gradually, he worked up a subtle and elaborate pretense of ennui: stared at himself in the dark mirror of the bar, as if lost in thought; fingered his glass, turning it round and round or sliding it slowly back and forth in the wet of the counter; shifted from one foot to the other; glanced at a couple of strangers standing farther down the bar and watched them for a moment or two, critical, aloof, and, as he thought, aristocratic; and when he finally did get around to raising the glass to his lips, it was with an air of boredom that said, Oh well, I suppose I might as well drink it, now that I've ordered it. (Jackson 1998: 16)

Much as the protagonist of his novel, Jackson had a history of drinking and struggling with alcoholic addiction, resulting in joining the AA and being hospitalised at the beginning of 1950s. As Bailey notes in his biographical study, Jackson "was indeed Don Birnam, and only two episodes in The Lost Weekend were purely fictional (to wit: he never pawned his girlfriend's leopard coat to get liquor money, nor did he stand up the hostess of his favourite bar because of an alcoholic blackout."); 2013: 4). It is interesting to notice how the novel translates Jackson's own alcoholic problems as a writer, with Birnam being both a tormented 
alcoholic and an equally tormented would-be novelist. This is so because he is obsessed with writing a novel he wants to call "In a Glass" ("The Bottle" in the film version), obviously based on his autobiographical experience. More to the point, he also refers to other writers afflicted with alcoholic addiction, such as Fitzgerald (1998: 136-138).

In a similar vein, Jackson's British counterpart, Malcolm Lowry, is "brilliantly insightful about the lure of alcohol" (Morrison 2013) in Under the Volcano. Much as The Lost Weekend, Lowry's novel became a classic of the alcoholic genre, also additionally popularised owing to its successful film version directed by John Huston in 1984. Jackson's and Lowry's protagonists have much in common: they both have a gargantuan thirst to quench, suffer from auditory and visual hallucinations, and in both cases the readers can observe their final degradation. Otherwise, the two novels have different styles, their alcoholic methodologies, as it were, belong to two different worlds:

The Lost Weekend is a portrait of alcoholic psychology and occurs entirely within the mind of its main character, Don Birnam. In Malcolm Lowry's however, Geoffrey Firmin's morbid alcoholism is part of a metaphorical web that illuminates both his individual experience of alcoholism and the human condition in a modern world shadowed by looming disaster. (Pratt 2015: 803)

In fact, Jackson's novel is a down-to-earth case study, almost a textbook for students of psychiatry, imbued with tiny details of alcoholic behavioural pattern, whereas Under the Volcano is allusive and metaphorical, if not mystical at times:

the Consul is engaged in a struggle of almost epic significance against dark, demonic, terrifying forces that are in large part represented or bodied forth by hallucinations. More heroic still, the Consul struggles not so much to avoid succumbing to the hallucinations as to make sense of them. Birnam's intelligence, though acute, is applied to less titanic aims: mainly to finding the means, financial and physical, to go on drinking. (Gilmore 1982: 287)

Lowry's novel is so much soaked with alcohol that Sam Jordison wonders whether there has been "a more alcoholic book than Under the Volcano?" (2013). It is, in fact, one of two novels Lowry managed to publish during his life, and one for which he is best known. It comes as no surprise that when a friend met drunk Lowry in London and asked him "what was next" he replied that he was working on "Under Under the Volcano." (cf. Max 2007). In fact, Lowry did write another contribution to drink literature in the form of an autobiographical novella, Lunar Caustic, its source of inspiration being Lowry's stay at a psychiatric ward of New York Bellevue Hospital in 1936. He continued revising Lunar caustic prior to his 
death in 1957 (cf. Knickerbocker 1979: 291, 292), but it was published posthumously in the Paris Review (1963) by Margerie Lowry and Earle Birney. This dark and bizarre story features Bill Plantagenet whose choice of a drinking den is rather morbid and disturbing, for he "likes drinking in churches particularly" (1979: 296). Even after leaving the hospital where Bill was taken for detoxification, he returns to his ultimate alcoholic sanctuary to plunge back into addiction:

He entered a church he knew, gazing about him. In the painting above, Christ was being offered a drink; he stood a while in meditation. The thought even of vinegar sent the blood coursing through his veins. There was only one other person there, a woman in black, kneeling. Here was his opportunity. When so much suffering existed, what else could a man do? With a guilty, flurried, yet triumphant motion he took a long draught of whisky." (345)

The part which seems a direct imprint of Lowry's own alcoholic ordeal, and which probably reflects his own observations while in hospital is the depiction of the DTs, which Donald Goodwin, who specialises in medicine and writes extensively on alcoholic writers, considers a superb literary rendition (cf. 1994: 48):

He needed a drink desperately. He did not know whether his eyes were closed or open. Horrid shapes plunged out of the blankness, gibbering, rubbing their bristles against his face, but he couldn't move. Something had got under his bed too, a bear that kept trying to get up. Voices, a prosopopoeia of voices, murmured in his ears, ebbed away, murmured again, cackled, shrieked, cajoled; voices pleading with him to stop drinking, to die and be damned. Thronged, dreadful shadows came close, were snatched away. A cataract of water was pouring through the wall, filling the room. A red hand gesticulated, prodded him: over a ravaged mountain side a swift stream was carrying with it legless bodies yelling out of great eye-sockets, in which were broken teeth. Music mounted to a screech, subsided. On a tumbled bloodstained bed in a house whose face was blasted away a large scorpion was gravely raping a one-armed Negress. His wife appeared, tears streaming down her face, pitying, only to be instantly transformed into Richard III, who sprang forward to smother him. (299)

Lowry and Jackson are undoubtedly two icons in the realm of drink literature, but there are numerous other examples worth critical attention. As American literature has been well documented in critical studies concerning drink-dependent writers and the way they depict alcoholism in fiction ${ }^{2}$, the British focus seems to offer more avenues that have not been properly acknowledged. The list of British

2 See, for example, Alcohol and the Writer (Donald Goodwin, 1988), The Thirsty Muse: Alcohol and the American Writer (Tom Dardis,1989) or Writing Under the Influence: Alcoholism and the Alcoholic Perception from Hemingway to Berryman (Matts Djos, 2010). 
writers $^{3}$ who were alcoholics is impressive, though some of them remain obscure, while many others are largely neglected in this particular aspect. Of those British novelists in whose life alcohol played as important a role as in their fiction two names are often mentioned. The first one ${ }^{4}$ is Evelyn Waugh, of whom his biographer, John Wilson, writes that "drinking detracted from his performance", and that he "loved drunken abandon" (2001: 22, 28). Donat Gallagher, in his collection of Evelyn Waugh's non-fiction, includes an essay entitled "Drinking”, in which Waugh gives an account of his early affection for alcohol: "It was at the university that I took to drink, discovering in a crude way the contrasting pleasures of intoxication and discrimination." (1983: 609). This affection was to be continued in later years and is superbly reflected in Brideshead Revisited (1945), which was filmed in 2008, directed by Julian Jarrold. The novel portrays Sebastian Flyte, whose family is not only of an aristocratic descent but also devoutly Catholic, and Charles Ryder, of a rather opposite background. Both young men forge a kind of friendship with a much deeper undertone on the part of Sebastian, and both of them partake in alcoholic binges organised by Sebastian, whose appearances in the novel are best described in a phrase used by his sister, Cordelia: "Old Sebastian on the spree again" (2000: 289).

Another British novelist for whom "heavy drinking was a part of his life" (Booth 1997: 15) is Graham Greene. The drink theme in his fiction is particularly well-expounded in three novels: The Power and the Glory (1940), whose protagonist is referred to as a 'whisky priest', not without a reason of course; Our Man in Havana (1958), with its famous scene of Captain Segura and James Wormold playing a game of draughts with miniature bottles of Scotch and bourbon; and The Honorary Consul (1973), namely Charles Fortnum, an alcoholic whose "veins run with alcohol, not blood." (2000: 44). Greene was exceptionally lucky with the film industry, because all the above were filmed, the first one as The Fugitive (1947, John Ford), a rather free version of the novel, the second and third under the same titles: Our Man in Havana (1959, Carol Reed) and The Honorary Consul (1983, John Mackenzie). Obviously, the fact that both Waugh's and Greene's novels have their film versions is conducive to their general appreciation, though at the same time, as the case of The Lost Weekend shows, it is often much to the detriment of the literary precursor's reception.

Much less apparent in the drink context is William Golding, though he did struggle with addiction for a long time. In the review of Golding's biography, Robert Douglas-Fairhurst underlines the following:

3 The Irish legacy of drink literature and drink-dependent writers offers enough material for a separate study; hence, it is not included here.

4 The missing name here is Kingsley Amis, because his overall contribution in the drink context, biographical and literary (including non-fiction) deserves a separate study. In fact, such work is now in progress (cf. Klepuszewski, Wojciech. The Proof is in the Writing: Kingsley Amis's Literary Distillations. To be published 2017/18). 
At no stage does John Carey refer to Golding as an alcoholic, but it is worth noting how often his account repeats the words "drink", "drank" and "drunk", creating a rhythm sadly suggestive of someone who may have enjoyed a drink but needed it even more. (2009)

Some of Golding's fiction offers interesting drink themes, including the characters' alcoholism, an example being The Paper Men (1984), whose protagonist, Wilfred Barclay, is an alcoholic writer. In fact, the opening pages of the novel immediately outline his bibulous nature:

I must interrogate the bottles. If it proved necessary, I must sneak out of the back door - no, the conservatory was quieter - get to the dustbin, ashcan, poubelle, whatever one chose to call it and, not to elaborate, count the empties. For the truth was that already I did not believe in the bottle still full but with the cork drawn. (1984: 9)

Interesting drink imagery can be found in The Inheritors (1955), a deeply disturbing novel in which the Neanderthals, Lok and Fa, discover the lure and the power of alcoholic drink:

His nose caught the scent of what they drank. It was sweeter and fiercer then the other water, it was like the fire and the fall. It was a bee-water, smelling of honey and wax and decay, it drew toward and repelled, it frightened and excited like the people themselves. There were other stones nearer the fire with holes in their tops and the smell seemed to come particularly strongly from them. Now Lok saw that when the people had finished their drink they came to these and lifted them and took more to drink. The girl Tanakil was lying in front of one of the caves as if she were dead. A man and a woman were fighting and kissing and screeching and another man was crawling round and round the fire like a moth with a burnt wing. (Golding 1981: 172)

However, among many numerous British writers who could be mentioned in the context discussed in this article, two figures deserve special attention, namely Jean Rhys and Patrick Hamilton, both recognised critically, though one could hardly call them mainstream writers, particularly Hamilton. Rhys and Hamilton are both sad figures, their lives entirely alcohol-ridden, their literary talent resulting in brilliant novels which remained forgotten for decades. Jean Rhys, after publishing some of her best novels, disappeared and indulged for years in solitary drinking, but was rediscovered and properly acknowledged. Rhys had a long and tragic history behind, alcoholism and prostitution included. As Elaine Savory writes in her study:

She gradually became a serious alcoholic and in middle age was arrested for disturbing the peace and was briefly confined in a woman's prison for psychiatric 
evaluation. Many assumed she had died when she disappeared from public view for decades, so when she reappeared, there was talk of a "reincarnation." (2009: ix)

Rhys herself describes her daily routine as determined by the drink intake: "One day drunk, two days hung-over, regular as clockwork." (quoted in Angier 1985: 92). In the drink context, some of her novels, particularly After Leaving Mr Mackenzie (1931) and Good Morning, Midnight (1939), offer interesting study material, with the main protagonists being vulnerable females, lonely and depressed in Paris, alcohol being of consolatory value, though the protagonist of Good Morning, Midnight, Sasha Jansen, is trying to drink herself to death thus establishing an escape route from her failed life:

I've had enough of these streets that sweat a cold, yellow slime, of hostile people, of crying myself to sleep every night. I've had enough of thinking, enough of remembering. Now whisky, rum, gin, sherry, vermouth, wine with the bottles labelled 'Dum vivimus, vivamus....' Drink, drink, drink. ... As soon as I sober up I start again. (2000: 37)

Even more disturbing is the case of Patrick Hamilton whose life perfectly matches his fiction. His alcoholic intake often amounted to three bottles of whisky daily (cf. Holroyd 2006: xx), which worsened his condition to such an extent that it disabled him from writing, leading to his death at the age of 58, cirrhosis of the liver being mostly to blame. Hamilton planned to write an autobiographical account of his alcoholism in Memoirs of a Heavy Drinking Man" (cf. Jones 2008: 5), but this was never completed; instead, there is an imprint of his life left in numerous novels. His fiction, much as his life, is drowned in an alcoholic haze, with the characters forever frequenting bars and pubs. The most pathographical novel of all is Hangover Square (1941), in which George Harvey Bone's obsession is so intense that drinking becomes part and parcel of his reasoning: "hadn't he got something to drink and think about?" (2001: 139). The monumental trilogy published in 1935 as Twenty Thousand Streets Under the Sky is similarly disturbing, though at the same time heart-rending, the hub of the story being The Midnight Bell, a pub in which the main characters' fortunes intertwine while drink flows in abundance.

Any discussion on the writer-drink-literature nexus is partly speculative, because it is difficult to quantify the extent to which fictional themes have their source in the writers' own alcoholic background. However, in most cases, this personal background is reflected in fiction, which is as 'fortified' as the authors' own lives: their personal stories, drinking patterns, and struggles with addiction conspicuously rendered in their novels. The fact that they are written from experience additionally validates their genuineness in the context of drink literature. 
Apart from numerous American novelists who have been extensively discussed in critical studies, and such iconic alcoholic writers as Lowry or Jackson, there are writers whose lives and works in the alcoholic context, have either not been considered at all, or largely ignored, without full acknowledgement of their personal entanglement and contribution to the field of drink literature. This is particularly true as regards the British writers, many of whom perfectly fit the context. Jean Rhys and Patrick Hamilton are just two examples, but there are numerous other, to mention Henry Green, or Julian MacLaren-Ross. The short space of this article does not allow for a detailed analytical dissection of the writer-drink-literature nexus, but it does signal that there are still novelists and novels worth further critical recognition in this respect.

\section{REFERENCES}

Angier, Carole. Jean Rhys. New York: Viking, 1985.

Blake Bailey. "Introduction to The Lost Weekend." New York: Vintage Books, 2013. Chandler, Raymond. The Long Good-Bye. Harmondsworth: Penguin Books in association with Hamish Hamilton, 1978.

Chandler, Raymond. The Big Sleep. New York: Vinatage Crime/Black Lizard, 1992.

Douglas-Fairhurst, Robert. "William Golding: the Man Who Wrote Lord of the Flies by John Carey: review.” The Telegraph, 28 August 2009.

Gilmore, Thomas B.1982. "The Place of Hallucinations in Under the Volcano." Contemporary Literature 23: 285-305.

Golding, William. The Inheritors. London: Faber and Faber, 1981.

Golding, William. The Paper Men. London: Guild Publishing, 1984.

Goodwin, Donald W. 1993. "Alcohol as Muse." Dionysos, Vol. 5 No 1, 1993, pp. 3-14.

Greene, Graham. The Honorary Consul: A Novel. New York: Simon and Schuster, 2000.

Hamilton, Patrick. 2001. Hangover Square. London: Penguin, 2001.

Hiney, Tom. Raymond Chandler: A Biography. London: Chatto \& Windus, 1997.

Holroyd, Michael. "Introduction to The Slaves of Solitude." In Hamilton, 2006. xiv-xiv.

King, Stephen. On Writing: A Memoir of the Craft. New York: Simon \& Schuster, 2002.

King, Stephen. Doctor Sleep. New York: Gallery Books, 2014.

Knickerbocker, Conrad. 1979. "Foreword to Lunar Caustic." In, Lowry, 1979. 291-293. 
Leith, Sam. 2013. “Doctor Sleep by Stephen King - review.” The Guardian, 30 September.

London, Jack. John Barleycorn. New York: Century Company, 1913.

Lowry, Malcolm. Hear Us O Lord from Heaven Thy Dwelling Place and Lunar Caustic. Harmondsworth: Penguin, 1979.

Max, D.T. "Day of the Dead: Malcolm Lowry's mysterious demise." The New Yorker, December 17, 2007.

Morrison, Blake. 2013. "Why do writers drink?" The Guardian, 20 July.

Pratt, David C. "Role of Alcohol in Literature." In Martin, Scott Christopher.

(Ed.), The Sage Encyclopedia of Alcohol: Social, Cultural, and Historical Perspective.

Thousand Oaks, CA.: SAGE Publications, 2015. 798-804.

Rhys, Jean. Good Morning, Midnight. London: Penguin, 2000.

Rolls, Albert. Stephen King: A Biography. Westport, Conn.: Greenwood, 2009.

Savory, Elaine. Jean Rhys. Cambridge: Cambridge University Press, 2004.

Seabrook, William. Asylum. New York: Harcourt, Brace and Company, 1935.

Seabrook, William. No Hiding Place. Philadelphia: J.B. Lippincott, 1942.

Waugh, Evelyn. Brideshead Revisited. London: Penguin Books, 2000.

Wilson, John Howard. Evelyn Waugh: A Literary Biography, 1924-1966. London: Associated University Presses, 2001.

Wilson, Edmund (ed.). The Crack-Up: Nonfiction by F. Scott Fitzgerald. New York: New Directions Publishing, 2009.

Wojciech Klepuszerwski Koszalin University of Technology klepuszewski@poczta.pl

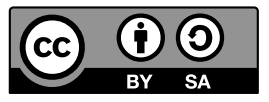

\section{Okrepljena proza: pisatelji in pijača}

Del tega kar je označeno za študije pitja zajema književnost in način na katerega je pijača opisana v literarnih delih. V mnogih primerih so takšna dela izpod peresa avtorjev, ki so sami odvisni od pijače.

Ključne besede: alkohol, književnost, proza, pisatelji, zasvojenost 